\title{
TARTÓSZERKEZETEK TERVEZÉSÉNEK MAI IRÁNYZATAI
}

\section{TODAY'S TRENDS OF STRUCTURAL DESIGN}

\author{
Kopenetz Lajos György ${ }^{1}$, Gobesz Ferdinánd-Zsongor ${ }^{2}$ \\ Kolozsvári Müszaki Egytem, Épitömérnöki Kar, Tartószerkezetmechanikai Tanszék, \\ Románia, 400020 Kolozsvár, C. Daicoviciu u. 15, 3. em., 305. \\ ${ }^{I}$ Telefon +40-264-401318, ludovic.kopenetz@mecon.utcluj.ro \\ ${ }^{2}$ Telefon: +40-264-401351, go@mecon.utcluj.ro
}

\begin{abstract}
Nowadays, more and more modern methods can be used in the design of bearing structures. Beside economic and safety issues, the designer can not ignore the correlations between built-in materials and target reaching technologies, also the implications of possible design modifications.
\end{abstract}

Keywords: structure, design, trend

\section{Összefoglalás}

A tartószerkezetek tervezése során manapság egyre korszerübb eljárások alkalmazhatók. A gazdasági és biztonsági szempontok mellett a tervező nem hagyhatja figyelmen kívül a beépített anyagok és a célelérési technológiák összefüggéseit, de az esetleges tervváltoztatások hatásait sem a szerkezetre.

Kulcsszavak: irányzat, tervezés, tartószerkezet

\section{1. Általános tervezési szempontok}

A mai szerkezeti tervezés a mérnöki alapismeretek mellett megköveteli a 3D -s tervezési technologiák és a BIM (Building Information Modelling) rendszer biztos hasznalatát. A BIM információs modellezési eljárás egy komplex folyamat, ami magaban foglalja az egész építészeti, szerkezeti, kivitelezési, épületgépészeti, beruházói és épületfenntartási folyamatot.

Mivel a szerkezeti tervezés egy szoros kapcsolatot feltételez a müépítészel és a beruházóval, nagy mértékben szükség van a kommunikációs kérdések alapos ismerete mellett a nehéz kérdések egyszerü magyarázatára. A tartószerkezet tervezése, mint iteratív folyamat, nagymértékben a tervezési paramétereken alapul. Ezeket a paraméte- reket sokszor építés közben és a használat idején is változtatni kell, s ezt a tervező köteles figyelemmel kísérni. A nagyon nagy épületek esetében, ha a kiviteli idő rendkívül szoros, a tartószerkezetet tervező érdemes, hogy az anyagjellemző paramétereket az alapértékük alatt vegye számításba, mert a kivitelezés közben általában nem változtathat a terven [1].

Sajnos, világhírü szakemberek véleménye szerint éppen ez a szemlélet hiányos, nagyon sok építész- és építőmérnök újat akar alkotni minden áron. Nervi P. Luigi világhírü mérnök szavait idézve: ,a statikai megoldások bösége nem szabad természetellenes statikai modellekhez vezessen, vagyis olyan szerkezetekhez, amelyek a statika személytelen törvényeiből erednek és amelyek erövel exhibicionista akrobatikát 
végeznek. Ez jelenti pillanatnyilag véleményem szerint a szerkezetépités legnagyobb veszélyét" [2].

A legmagasabb rendü mérnöki tevékenység a rendeltetésszerüen és esztétikailag legértékesebb változat kiválasztását jelenti a sok közül. Ez az alkotó munka adja a szerkezettervezés szépségét, mert automatikusan még nem lehet kiválasztani a legjobb megoldást épp úgy, ahogy a számítógépek megoldják az egyenleteket, de a programozást szakemberek végzik.

Nyilván, az egyetemi oktatásban az építőmérnöki karokon rendet kell rakni a gigantikus információ-halmazban a tervezési technológiák és térinformatikai rendszerek, meg az alap tantárgyakkal való egyenlő óraszám beiktatásával, valamint szervezett oktatásával. Itt meg kell említeni, hogy a jövendő építőmérnökök elegendő információt kellene kapjanak a tervezési irányokról, úgy a hazai, mint a külföldi projekt rendszerekről, mert ma már egyre több országban ugyanazokat a tervezési szoftvereket használják.

\section{A tartószerkezetek kiválasztása}

A mai tartószerkezeteknek az alábbi igényei vannak:

- gyors kivitelezés, lehetőleg kevés beépített szerkezeti anyaggal;

- technológiai kötöttségeket nem okozó szerkezet, illetve támasz kiosztás;

- megfelelő világítás, müszaki vezetékek és szerelvények megfelelő elhelyezése;

- bővíthetőség;

- alacsony karbantartási költségek.

Szerkezeti szempontból látszólag a statikai határozatlanság előnyös, mivel a többletkötések csökkentik a szükséges keresztmetszeteket és így gazdaságosabb eredményt kapunk. Nyilvánvaló, hogy egy többtámaszú tartó alkalmazása előnyősebb mintha kéttámaszú tartók sorozatával próbálnánk ugyanazt a távolságot, ugyanakkora terheléssel kiváltani, de az előregyártás a példa rá, hogy ez nem általános érvényü megállapítás, hiszen sok esetben a kéttámaszúként gyártott és beszerelt tartók bizonyulhatnak gazdaságosabbnak.

A kötélszerkezetek szintén előnyösek lehetnek, hiszen kisebb anyagmennyiséget foglalnak magukba és kivitelezésük elég gyors (kedvező szerkezeti megoldás az, amikor egyszeri statikai határozatlansággal rendelkeznek, mivel ilyen esetekben jól kivitelezhetők és gazdaságosak). Vékony héjú (pl. ponyva) szerkezetekkel kombinálva jól alkalmazhatók nagy fesztávú könnyü tetők kialakításához.

$\mathrm{Az}$ építési idő lerövidítése lett $\mathrm{az}$ építőipari beruházások leghangsúlyozottabb tényezője. Ennek a tényezőnek a gazdasági hatását és a megfelelő számítási, szabási módját ma már általánosabban ismerik és alkalmazzák mint régen. A jelenleg alkalmazható technológiák rendkívúl gyors ütemben fejlödnek, így az épületszerkezeteknek (és a tervező, illetve kivitelező szakembereknek is) tudniuk kell alkalmazkodni ehhez a változáshoz a piacképesség érdekében. Több esetben is elképzelhetö, hogy a technológia változásával az épületet is ki szeretné cserélni a befektető, bár erre a gyakorlatba még nem alakult ki általános érvényü gazdaságos müszaki megoldás. Tény viszont, hogy az aránylag könnyen átalakítható, változatosabb alkalmazhatóságú tartószerkezetek sok esetben előnyt jelenthetnek.

A rugalmas építési mód elsősorban a nagyméretủ fesztávokkal próbál megoldást kínálni erre a problémára, mivel, ha megfelelő szerkesztési elv kerül alkalmazásra, akkor a költségek nem fogják lényegesen meghaladni a kisseb méretekre szabott változatok összesített árát, a bontási munkálatok költségétől pedig el is lehet tekinteni. $\mathrm{Az}$ alkalmazott fesztávok leginkább 18 és $30 \mathrm{~m}$ közöttiek (a legkisebbek 12-15 m értéküek, míg a legnagyobbak elérhetik a 60-100 m-t is). Számszerint, az építkezések túlnyomó többségét e téren a csarnok szer- 
kezetek alkotják, ezek közül is a földszintes típusokból építik a legtöbb darabot, és ez világszerte növekvő tendenciát mutat (föleg az olcsó és gyors szerelhetőség miatt, ami bizonyos rugalmasságot is biztosíthat a müszaki és a gazdasági igények függvényében). A tartószerkezet bővítésének egyik nagy problémája az, hogy mennyire állnak rendelkezésre, illetve mennyire hozzáférhetők az eredeti szerkezeti elemek. Ebből a szempontból a legproblematikusabbak talán a vasbeton tartószerkezetek, mivel a sarokmerevséget biztosító részeket már az eredeti szerkezetnél előrelátóan ki kellene képezni és az alapozás kialakításánál is megfelelően előretekintően kéne eljárni. Az ipari létesítmények esetében a bővítések és átalakítások a technológiai vezetékekben, szerelvényekben és a szerkezethez kötődő belső szállításhoz szükséges berendezésekben nagyon lényeges változásokat okozhatnak.

A lassú hatások nagy mértékben megváltoztathatják a tervezésnél használt alapadatok nagyságrendjét, ha a felújítás alatt a szerkezet meglévő egyensúlyán a funkcióváltozás ilyen irányba hat. Mivel az állandó jellegü természetes terhelés egyenletesen megoszló (önsúly, szél, hó, víznyomás stb.), akkor maximális a tartószerkezet hatásfoka, amikor alakja olyan tiszta forma felé törek-szik, amelyik összhangban van a statikával és a mozgási ellenállások törvényeivel. A lényeg tehát, az alapvető strukturális elkép-zelés, míg a statikai modell és a méretezési eljárás csupán eszköz.

\section{A szerkezeti tervezés és a szerkezeti anyagok}

A tartószerkezet megválasztásánál a funkció és a forma melett figyelembe kell venni a gazdaságosságot, a költségek méretét. Mérnöki szempontból a gazdaságosságra való törekvés alatt az alkalmazott anyagok mennyiségi csökkentését értjük elsősorban. Közismert tény, hogy a magassági rekordot hajkurászó rendkívüli építményeknél már nem alkalmazható tiszta acélszerkezet, hiszen sem elegendő nyersanyag, sem megfelelő termelési kapacitás nem áll rendelkezésre a beruházás futami ideje alatt.

$\mathrm{Az}$ új szerkezetekhez használt építőanyagok jól meghatározott anyagjellemzöivel szemben a régi (történelmi) épületeknél kevés anyagminta alapján becsült tervezési paramétereket veszünk alapul. Ilyen esetekben nem alkalmazhatók egyértelmúen az érvényes szabványok, és tervezési módszereket sem lehet feltétel nélkül megbízhatómak tekinteni.

Az építmények anyagának a kiválasztása nagyrészt a karbantartási költségek függvénye. Jelenleg leginkább az acél és a vasbeton, kevésbé a fa jön számításba. A fa ára egyre nő, rendkívül érzékeny a légköri hatásokra, a tüzállósága is korlátozott, de mivel sok helyen hagyományosan hozzáférhető, megújuló nyersanyag, könnyen megmunkálható és sajátos esztétikával bír, ezért nem lehet kirekeszteni még az ipari épületszerkezetek alkótóelemeinek az anyagai közül sem. Az utóbbi időben a müszaki fejlődés olyan eredményeket hozott (pl. műanyagokkal ragasztott szekrényes rácstartók, laminált gerendák és ívtartók, új impregnálási és felületkezelési módszerek a biológiai kártevők és a tűz elleni hatásos védekezéshez), amelyek a faszerkezetek felhasználási területén új adottságokat teremtettek. A legelterjedtebb alapanyagok mégis az acél és a vasbeton maradtak.

$\mathrm{Az}$ ipari módszereknek az építöipari elterjedésével párhuzamosan növekedett az acélszerkezetek alkalmazása, több okból kifolyólag is. Az acélszerkezet súlya lényegesen kisebb a vasbeton szerkezetnél (kisebb építőgépek alkalmazhatók, gyors és könnyü a szerelés, könnyebb alapozás szükséges, egyszerübb a szállítás), a gyártás kizárólag ipari jellegü, bontás esetén a szerkezet anyaga visszanyerhetö nyersanyagként (vasbeton esetében ez sokkal 
körülményesebb), a fesztávok kialakítását könnyebben és változatosabban lehet megoldani. Ezzel szemben, a vasbeton szerkezetek olcsóbbak, nincsen akkora korróziós problémájuk és a tüzzel szemben is ellenállóbbak. E három, hagyományosnak számító anyag mellett jelentkezik az aluminium és a műanyagok. Az aluminium alapanyagú szerkezetek korrózióállósága (ami az acélszerkezetek leglényegesebb gyöngéje) és csekély súlya nagy előnyt jelentenek szerkezeti szempontból, de anyagi szempontból ma még túl sokba kerülnek. Egyik lehetséges felhasználási módjuk az összetett, szendvics vagy kompozit panellek alkalmazásában rejlik, ahol a vékony héjborításban lemezvastagságként elég egy $0,4-1,5 \mathrm{~mm}$-es aluminium réteg. A műanyagok ma még csak másodrendü szerkezetként szerepelnek, föleg épületgépészeti elemekként és nyílászárók meg homlokzatok burkoló- vagy védőrétegeként kerülnek alkalmazásra, de a jövőben tartószerkezetként is valószínüleg nagyon el fognak terjedni, elsősorban a héjszerkezeteknél.

Szintén az újabb építési módszerek közé tartoznak a függesztett tetők alkalmazásai, mivel anyagtakarékosak, kicsi a súlyuk, könnyen szállíthatóak és szerelhetőek. A héjszerkezetek és a függőtetők méretezése aránylag bonyolult, így a jelenlegi viszonyok között csak kb. 18-24 m fesztávolság felett képesek felvenni a versenyt gazdaságosabb tervezési-építési költségek szempontjából a feszített vasbetonszerkezetekkel.

\section{A tartószerkezetek biztonsága}

A tartószerkezeti tervezés biztositási költségeinek a hazai megjelenése, valamint ezeknek az öszegeknek a váratlan nagysága egy újabb kérdés amit a közeljövőben meg kell oldani. A tervezés során így már a start helyzetben jelentkeznek külünböző vészhelyzetek, nem csak a kivitelezés meg a többi szakág bekapcsolodása folyamán. E szempontok egy új tervezési paradigmában jelentkeznek, amit kockázatanalízisnek nevezünk. A kockázatanalízis eredménye egy olyan technikai megoldás elöírása, ami a balesetek elkerülésének a legmegfelelőbb útját jelenti. Sajnos sok tervező ezt nem tartja fontosnak és így ez a vizsgálat nincs is rögzitve a szerződésekben. Ez sok esetben óriási veszélyt jelent, mert a szerkezetre ható erők építés közben sok bizonytalanságot rejtenek.

\section{Következtetések}

A teherhordó szerkezetek közül azok a legelőnyösebbek, amelyek a természetes erőjátéknak a legjobban megfelelnek, (a teher a legközvetlenebbül vagy a legrövidebb úton kerül a talajra).

A kiviteli tervekkel kapcsolatban manapság a tervező gyakran bekapcsolódik a kivitelezési tevékenységekbe, tervezöi müvezetőként (ez a nagyon bonyolult tervek esetében szinte nélkülözhetetlen). Így gyorsan megoldódhatnak a szerkezeti anyag és a célelérési technológiák összefüggései, valamint a tervváltoztatások hatásai a szerkezetre, illetve a hatályos előírások alól való felmentés a biztonság javára. A tervezők a könnyü kivitelezhetőséget eddig kevésbé tartották szem elött, leginkább csak az anyagmutatók alapján döntöttek egy-egy szerkezet megfelelőségét és alkalmazhatóságát illetően. A nagy munkaigény nagyon hátrányos egy szerkezetre, tehát minden tartószerkezet megítélésében fontos szerepet kéne játszon. A befektetők szempontjából elvileg a rövid építési idő a legfontosabb, hiszen minél hamarabb használható az építmény, annál hamarabb fog hasznot hajtani.

\section{Szakirodalmi hivatkozások}

[1]Kopenetz L. G.: Gondolatok statikusoknak, Kriterion Könyviadó, Kolozsvár, 2006.

[2]Nervi P. L.: Aesthetics and Technology in Building, Harvard University Press, Cambridge, 1965. 